\title{
Victims and the Sentencing Process: Developing Participatory Rights?
}

Jonathan Doak, Nottingham Trent University

Ralph Henham, Nottingham Trent University

Barry Mitchell, Coventry University

Recent years have seen a number of developments pertaining to the notion that victims should be afforded a 'voice' in the criminal justice system. The theoretical and structural parameters of the adversarial system are not, however, conducive to exercising such a role. For many, conferring procedural rights on victims jeopardises the due process rights of the accused, as well as the public nature of the criminal justice system. In light of the recent decision to roll out the 'Victims' Focus Scheme' across England and Wales, this article explores a number of issues of principle that arise - not least the deeper policy implications of an apparent re-alignment of the normative parameters of the criminal justice system to incorporate the private interests of third parties.

10,429 words excl. footnotes 


\section{Victims and the Sentencing Process: Developing Participatory Rights?}

\section{Introduction}

Over the course of the last 30 years or so, the problems facing victims in the criminal justice system have become ever more apparent. Successive governments have sought to capitalise on the lucrative political appeal of the crime victim, ${ }^{1}$ and have implemented a range of reforms primarily targeted at providing additional support and protection for victims. As Ashworth has observed, more has been promised than delivered in recent years in relation to victim services, ${ }^{2}$ though on the whole such reforms have received a relatively warm reception. However, the idea of conferring procedural rights on victims of crime (ie, the notion that they should be allowed to participate in the criminal process) has always proved much more contentious.

The concept of victim participation is nothing new; as long ago as 1990, probation officers, using either CPS papers or victim statements, were obliged to assess and comment on the impact of the consequences of the offence on victims in their pre-sentence reports. ${ }^{3}$ This scheme was effectively expanded in October 2001 with the introduction of the Victim Personal Statement Scheme (VPSS) ${ }^{4}$ which required the police to inform victims of the right to

\footnotetext{
${ }^{1}$ On the potentially political appeal of the crime victim, see further G Geis, 'Crime victimspractices and prospects' in A Lurigio, WG Skogan and RC Davis (eds), Victims of Crime: Problems, Policies, Programs (Newbury Park, CA, Sage: 1990); D Garland, The Culture of Control: Crime and Social Order in Contemporary Society (Oxford: Oxford University Press, 2001); CA Warner and JL Rudolf, 'Mandatory Compensation Orders for Crime Victims and the Rhetoric of Restorative Justice' (2003) 36 Aust NZJ Criminol 60.

${ }^{2}$ A Ashworth, Sentencing and Criminal Justice (Cambridge: Cambridge University Press, $2^{\text {nd }}$ ed,, 2005), 353.

${ }^{3}$ National Standards, National Standards for the Supervision of Offenders in the Community (London: Home Office, 2000).

${ }^{4}$ Home Office, Victim Personal Statement Scheme: Circular 35/2001, (London: HMSO, 2001). The VPSS was introduced notwithstanding research evidence reflecting problems in the pilot projects; see C Hoyle, R Morgan \& A Sanders, The Victims' Charter: an evaluation of pilot projects (London: Home Office, 1999). Any VPS had to be in the form of a section 9
} 
include comments about the impact of the offence in any statement they may make. ${ }^{5}$ In September 2005, the Government was persuaded that it should take the concept of victim allocution one step forward, and decided to pilot the use of 'family impact statements' in court. This was to allow the families of victims of murder or manslaughter to make an oral statement on the impact of the offence, post conviction but before sentence was passed. Thus, the Victims' Advocates Scheme (VAS) was established in five Crown court centres, and ran from April 2006 to April $2008 .^{6}$

This article examines the VAS and its repackaged successor, the Victim Focus Scheme (VFS), against emergent international trends and the apparent realignment of the normative parameters of the criminal justice system. In particular, we consider the impact of how the 'public' nature of criminal justice processes has been increasingly exposed to private interests, thereby exposing ideas about crime and punishment to more holistic understandings of concepts of harm, fault, retribution and reparation. These shifts are not without consequence: the capacity of the adversarial system to accommodate a proactive role for the victim is highly apposite - given its inherent conception as a two-way conflict between the state and the offender. The victim, it would seem, now stands on the brink of recapturing this conflict.

witness statement or in an expert's report and served on the defence before sentence was passed: the sentencing court should take into account, as far as it considered appropriate, "the consequences to the victim"; see Practice Direction (Victim Personal Statements) [2002] Cr App R (S) 482.

${ }^{5}$ However, since 2005, the Victims' Code of Practice ceased to require the police to inform victims of this right other than in cases of murder and manslaughter: Home Office, Hearing the Relatives of Murder and Manslaughter Victims: Consultation Document (London: HMSO, 2005).

${ }^{6}$ The pilot centres were the Central Criminal Court (the Old Bailey), and the Crown Courts at Birmingham, Cardiff, Manchester and Winchester. Effectively, the VAS has now been superseded by the Victim Focus Scheme (originally announced by the Attorney-General in October 2007) which continues to enable the families of murder and manslaughter victims to work with prosecutors on the preparation of an impact statement which is subsequently read out in court. 


\section{Rights of Participation: the Arguments and Counter-arguments}

The potential drawbacks and benefits of participatory mechanisms have received considerable attention in the literature. Before rehearsing these arguments, it is worth emphasising that empirical studies tend to suggest that victims do not actually seek decision-making power. ${ }^{7}$ By contrast, they tend to prioritise recognition, acknowledgement and some form of participatory role. ${ }^{8}$ To this end, a range of empirical studies confirm that victim participation increases satisfaction with justice through giving victims a sense of empowerment and official, albeit symbolic, acknowledgement. ${ }^{9}$

${ }^{7}$ See eg J Shapland, J Willmore, and P Duff, Victims and the Criminal Justice System (Aldershot: Gower, 1985); Justice, Victims in Criminal Justice, Report of the Justice Committee on the Role of Victims in Criminal Justice (London: JUSTICE, 1998); J Wemmers and K Cyr, 'Victims' Perspectives on Restorative Justice: How Much Involvement Are Victims Looking For?' (2004) 11 IRV 259.

${ }^{8}$ DG Kilpatrick, D Beatty and S Smith Howley, The Rights of Crime Victims-Does Legal Protection Make A Difference? (Washington DC: US Dept of Justice, 1998). It may be noted, however, that data from a number of participatory initiatives, such as restorative justice schemes and victim statement schemes do contain relatively low take-up rates by victims (see eg R. Morgan, and A. Sanders, The Use of Victim Statements (London: Home Office, 1999); Newburn, T, Crawford, A, Earle, R, et al. The Introduction of Referral Orders into the Youth Justice System, Home Office Research Study 242 (London: Home Office, 2001); Hoyle, C, Young, R, and Hill, R (2002) Proceed with Caution: An Evaluation of the Thames Valley Police Initiative in Restorative Cautioning (York: Rowntree, 2002). However, this may be because of the way in which such schemes were implemented in practice. For an excellent overview of what 'participation' should entail, see I Edwards, 'An Ambiguous Participant: The Crime Victim and Criminal Justice Decision-Making' (2004) 44 BJC 967.

${ }^{9}$ See eg. H Kury and M Kaiser, 'The Victim's Position within the Criminal Proceedings-An Empirical Study' in G Kaiser, H Kury, and H-J Albrecht (eds), Victims and Criminal Justice: Legal Protection, Restitution and Support (Freiburg: Max Planck Institute, 1991); E Erez and E Bienkowska 'Victim Participation in Proceedings and Satisfaction with Justice in the Continental Systems: The Case of Poland' (1993) 21 JCJ 47; Shapland et al, above n 7; E Erez, L Roeger and F Morgan, 'Victim Harm, Impact Statements and Victim Satisfaction with Justice: An Australian Experience' 5 (1997) IRV 37. A study of victims in the Dutch criminal justice system has also suggested that many victims feel that procedures which even allow passive participation in the criminal trial carry a certain symbolic importance for many victims which, in turn, can reduce feelings of exclusion and unfairness: J Wemmers, Victims in the Criminal Justice System (Amsterdam: Kugler, 1996), 338. 
Calls for enhanced participatory rights for victims have rested on various different arguments. It is alleged, for example, that more meaningful participation contributes to overall levels of victim satisfaction and thereby bolsters the legitimacy of the criminal justice system as a whole. ${ }^{10}$ From a moral standpoint, it has been suggested that it is only right that victims have an opportunity to play a role in the delivery of punishment, since this can provide some measure of reassurance to them that they have public recognition and support. ${ }^{11}$ On a more pragmatic level, it might be added that such statements ensure that courts are presented with a more complete picture of the crime and are thereby better placed to sentence the offender and order reparation to the victim. ${ }^{12}$

Yet even if we accept, wholly or partially, the validity of these arguments, we cannot escape the fact that victims' participatory rights are inherently foreign to the normative parameters of the English criminal justice system. In a seminal article, Nils Christie outlined an historical pattern, whereby the state 'appropriated' the criminal conflict from the victim and thereby transformed a private dispute between individuals into a transgression against the state. ${ }^{13}$ Thus the parameters of 'criminal' behaviour are laid down by the state to punish conduct that is deemed to be sufficiently injurious to the public at large. In this sense, the interests of the victim in common law systems are notionally

\footnotetext{
${ }^{10}$ See eg N Walker and M Telford, Designing Criminal Justice: The System in Comparative Perspective, Report 14, Review of the Criminal Justice System in Northern Ireland (Belfast: HMSO, 2000); C Brennan, 'The Victim Personal Statement: Who is the Victim?' (2001) 4 Web JCLI.

${ }^{11}$ A Cretney and G Davis, Punishing Violence (London: Routledge, 1996) at 178; M Cavadino and J Dignan, 'Reparation, Retribution and Rights' (1997) 4 IRV 233.

12 S Hillenbrand and B Smith, Victim Rights Legislation: An Assessment of its Impact on Criminal Justice Practitioners and Victims (Chicago: American Bar Association, 1989); J. Chalmers, P Duff, and F Leverick 'Victim impact statements: can work, do work (for those who bother to make them)' [2007] Crim LR 360.

${ }^{13} \mathrm{~N}$ Christie, 'Conflicts as Property' (1977) 17 BJ Crim 1. For a critique of this argument, see J Gardner, 'Crime: in Proportion and in Perspective' in A. Ashworth and M. Wasik (eds.),

Fundamentals of Sentencing Theory (Oxford: Clarendon Press, 1998).
} 
conceptualised as falling outside the criminal law, and should instead be pursued through the civil courts. The function of the victim within the criminal justice system is primarily instrumental; those who have suffered the primary effects of victimisation have been 'conscripted' into an operational role of assisting the criminal justice system in bringing offenders to justice. ${ }^{14}$ This conception both denigrates victims ${ }^{15}$ and also tends to portray their rights and interests in discrete and opposing terms to those of offenders. ${ }^{16}$ Moreover, such a view also highlights an underlying tension in the relationship between victims and Crown Prosecutors. Certainly, as far as the VAS is concerned, the very idea of victims relying on their own counsel is fundamentally alien to the adversarial tradition - at least since its 'adversarialisation' in the nineteenth century. ${ }^{17}$ To date, victims have traditionally been dependent upon the Crown Prosecutor to safeguard their interests. Prosecutors, in turn, are required to perform a juggling act, combining their normative roles as 'a minister of justice' pursuing the public interest with distinct obligations to support third parties. ${ }^{18}$ Indeed, in Sweeting et al's partial evaluation of the VAS in $2007,{ }^{19}$ it was apparent that the potential for conflict was a significant concern in the eyes of some of the practitioners, particularly given the prosecution's duty to

\footnotetext{
${ }^{14}$ D Faulkner, Crime, State and Citizen (Winchester: Waterside Press, 2001), p 226.

${ }^{15}$ A Duff, 'Restoration and Retribution' in A Von Hirsch, J Roberts, AE Bottoms, et al (eds),
} Restorative Justice and Criminal Justice: Competing or Reconcilable Paradigms? (Oxford: Hart Publishing, 2003).

${ }^{16} \mathrm{~J}$ Dignan, Understanding Victims and Restorative Justice (Maidenhead: Open University Press, 2005).

17 See further JH Langbein, The Origins of the Adversary Criminal Trial (Oxford: Oxford University Press, 2003).

${ }^{18}$ See $R v$ Banks [1916] 2 KB 621, where the court held, citing $R v$ Puddick (1865) 4 F \& F 497 , that 'prosecuting counsel should regard themselves as ministers of justice assisting in its administration rather than advocates' (at 499). See further J. Doak, Victims' Rights, Human Rights and Criminal Justice: Reconceiving the Role of Third Parties (Oxford: Hart, 2008), at 118.

${ }^{19}$ A Sweeting, R Owen, C Turley et al, Evaluation of the Victims' Advocate Scheme Pilots, Ministry of Justice Research Series 17/08 (London: Ministry of Justice, 2008). See also P. Rock, 'Hearing Victims of Crime': The Delivery of Impact Statements as Ritual Behaviour in London Trials for Murder and Manslaughter' in A.E. Bottoms and J. Roberts (eds) Victims in the Criminal Justice System (Cullompton: Willan, 2009). 
disclose information about the victim that the family may not wish to publicise. ${ }^{20}$

On a theoretical platform, the state is conceived as the notional 'victim', whilst those who have actually suffered the primary consequences of the offending behaviour are viewed as awkward outsiders to the process. ${ }^{21}$ On this basis, commentators have warned that schemes like the VAS, alongside other participatory mechanisms, would fundamentally distort the public nature of the criminal justice system or would interfere with the protection of the rights of accused persons and offenders. ${ }^{22}$ More specifically, it has been contended that victim participation is morally inconsistent with the traditional rationales underlying sentencing. ${ }^{23}$ In particular, concerns have been addressed as to whether it is legitimate for sentence to vary in accordance with the potentially unforeseeable results of an offender's conduct. It is thus feared that victim participation, particularly within the sentencing process, could introduce a new and unpredictable variable into the penalty equation and would jeopardise core principles such as just-deserts, proportionality, certainty and objectivity. ${ }^{24}$

As Erez et al acknowledge, some commentators fear a 'reversion to the retributive, repressive and vengeful punishment of an earlier age'. ${ }^{25}$ Certainly, there are few who would dispute that it is imperative that, as a matter of public

${ }^{20}$ Sweeting et al, ibid, 17 . This may be particularly problematic where the information concerns the victim's previous convictions or involvement with gangs.

${ }^{21} \mathrm{H}$ Zehr, Changing Lenses: A New Focus for Crime and Justice (Waterloo, ON: Herald Press, 3rd ed, 2005).

22 See eg. A Abramovsky, 'Victim impact statements: Adversely impacting upon judicial fairness' (1992) 8 St. John's Journal of Legal Commentary 21; A Ashworth, 'Victims' Rights, Defendants' Rights and Criminal Procedure' in A Crawford and J Goodey (eds), Integrating a Victim perspective within Criminal Justice (Aldershot: Ashgate, 2000).

${ }^{23}$ See eg DJ Hall, 'Victims' Voices in Criminal Court: The Need for Restraint' (1991) 28 Am Crim L Rev 233; Y Buruma, 'Doubts on the Upsurge of the Victim's Role in Criminal Law' in $\mathrm{H}$ Kaptein and M Malsch (eds), Crime, Victims, and Justice, Essays on Principles and Practice (Aldershot: Ashgate, 2004).

${ }^{24}$ See further J Gardner, above $\mathrm{n} 13$.

${ }^{25}$ E Erez, L Roeger, and F Morgan, above n 9. 
policy, victims should not be allowed to use any locus standi they are granted to engage in a character assassination exercise against the accused. Inflammatory statements of hatred or an expressed desire for revenge could readily be subject to cheering from the public gallery or sensationalist reporting in the popular press. Considerable care does, however, need to be taken in making assumptions about what victims actually seek through participating in the criminal process. Whilst many victims may experience deep-seated feelings of anger and bitterness in the aftermath of an offence, studies have tended to suggest that victims would seem to be no more punitive than the general public in relation to their attitudes to sentencing by criminal courts. ${ }^{26}$ In their evaluation of the VPS pilots, Hoyle et al found that, 'rather than... encouraging exaggeration, inflammatory statements, and vindictiveness, the opposite appears to apply: they [victim personal statements] tend to understate rather than over-state the impact of offences. $^{27}$ Similarly, Chalmers et al found that victim impact statements made as part of a Scottish scheme were often vague in terms of laying down specific demands. Some statements even showed that victims were concerned about 'their' offenders and requested a lighter sentence. ${ }^{28}$ Studies into the motivations of victims participating in restorative initiatives have also found that far from seeking vengeance, most victims prioritise restitution or compensation over retribution. ${ }^{29}$

${ }^{26}$ E Erez and P Tontodonato, 'The Effect of Victim Participation in Sentencing on Sentence Outcome' (1990)28 Criminology 451; M Hough and A Park, 'How malleable are attitudes to crime and punishment? Findings from a British deliberative poll' in J. Roberts and M. Hough (eds), Changing Attitudes to Punishment. (Cullompton: Willan, 2002); J Mattinson and C Mirrlees-Black, Attitudes to Crime and Criminal Justice: Findings from the 1998 British crime Survey (London: Home Office, 2000).

${ }^{27}$ C Hoyle, E Cape, R Morgan, and A Sanders, Evaluation of the One Stop Shop and Victim Pilot Statement Projects (London: Home Office, 1998) at 28.

${ }^{28}$ Chalmers et al, above n 12, p 374.

${ }^{29}$ See eg C Hoyle, R Young, and R Hill, Proceed with Caution: An Evaluation of the Thames Valley Police Initiative in Restorative Cautioning (York: Rowntree, 2002); J Shapland, A Atkinson, $\mathrm{H}$ Atkinson et al, Restorative Justice in Practice-findings from the second phase of the evaluation of three schemes, Home Office Research Findings 274 (London: Home Office, 2006); C Campbell, R Devlin, D O'Mahony, et al, Evaluation of the Northern Ireland Youth 
The tendency of the criminal law to prioritise the collective interests of society over those of individual victims is justified primarily on the basis that crime is harmful to society. The form of censure imposed by the courts thus symbolises a public denunciation of the offender's wrongdoing. Thus the individual desires of victims in relation to punishment- irrespective of whether they be forgiving or vengeful in their nature - risk usurping the key public interest values and objectives of the criminal justice system. ${ }^{30}$ This is a view that seems to have found favour in the higher courts, as Judge LJ explained in $R v$ Nunn: $:^{31}$

'We mean no disrespect to the mother and sister of the deceased, but the opinions of the victim, or the surviving members of the family, about the appropriate level of sentence do not provide any sound basis for reassessing a sentence. If the victim feels utterly merciful towards the criminal, and some do, the crime has still been committed and must be punished as it deserves. If the victim is obsessed with vengeance, which can in reality only be assuaged by a very long sentence, as also happens, the punishment cannot be made longer by the court than would otherwise be appropriate. Otherwise cases with identical features would be dealt with in widely differing ways, leading to improper and unfair disparity, and even in this particular case...the views of the members of the family of the deceased are not absolutely identical. ${ }^{32}$

Conference Service NIO Research and Statistics Series: Report No. 12 (Belfast: Northern Ireland Office, 2006).

30 See A Ashworth, 'What Victims of Crime Deserve' paper presented to the Fulbright Commission on Penal Theory and Penal Practice, University of Stirling, September 1992; 'Some Doubts About Restorative Justice' (1993) 4 Criminal Law Forum 277; D Garland, Punishment and Modern Society (Chicago: University of Chicago Press, 1990), 252; J Gardner, above n 13; Buruma, above n 23; R Coen 'The Rise of the Victim-A Path to Punitiveness?' (2006) 16 ICLJ 10.

${ }^{31} R$ v Nunn [1996] 2 Cr App R (S) 136.

32 Ibid, 140. 
While unpredictable variations in sentence would lead to a lack of certainty and be seen as undermining the rights of the accused, such a view may exaggerate the extent to which the consequences are likely to be unforeseen by the perpetrator. ${ }^{33}$ Nevertheless, the appellate courts have opted to tread cautiously in allocating weight to the views expressed by victims in relation to a sentence. In Perks, ${ }^{34}$ Garland J. reviewed the authorities and concluded that (a) any assertion that a victim had suffered as a result of the offence should be supported by evidence; otherwise, it should be inadmissible. Further, '[e]vidence of the victim alone should be approached with care, the more so if it relates to matters which the defence cannot realistically be expected to investigate'. ${ }^{35}$ Moreover,

'the opinions of victims and/or their relatives as to what sentence should be passed should not be taken into account. The court must pass what it judges to be the appropriate sentence having regard to the circumstances of the offence and of the offender subject to two exceptions: (i) where the sentence passed on the offender is aggravating the victim's distress, the sentence may be moderated to some degree; and (ii) where the victim's forgiveness or unwillingness to press charges provides evidence that his or her psychological or mental suffering must be very much less than would normally be the case. $^{36}$

\footnotetext{
${ }^{33} \mathrm{H}$ Fenwick, 'Procedural Rights of Victims of Crime: Public or Private Ordering of the Criminal Justice Process?' (1997) 60 MLR 317.

${ }^{34}$ [2001] 1 Cr App R (S) 19.

${ }^{35} \mathrm{Ibid}$, [H6], citing Lord Bingham CJ in $R v$ Roche [1999] 2 Cr App R (S) 105. Here, the offender pleaded guilty to causing the death of his cousin by careless driving while under the influence of drink or drugs. The Court of Appeal accepted a court might, as an act of mercy, reduce a sentence if the relatives of the victim indicated that the punishment imposed on the offender was aggravating their distress

${ }^{36}$ Ibid, [15]. These principles were later incorporated in Consolidated Practice Direction [2002] 1 WLR 2870.
} 
Whilst the tenor of the decision in Perks was largely sceptical of the role that victims' emotions could play within sentencing, it was apparent from the decision that the impact of the offence, and degree of harm caused to the victim, were factors that could be legitimately considered. In other words, the Court had effectively acknowledged that the interests of the victim were part and parcel of the greater public interest. ${ }^{37}$ In the years since the Court of Appeal's decision, conceptions of criminal responsibility expanded to take even closer account of the nature of the harm or loss suffered (or threatened) to the victim. For example, Schedule 21 of the Criminal Justice Act 2003 provides that for those convicted of murder the starting point of the minimum term should be a whole life or 30 years - i.e. longer than would otherwise be the case - where there is more than one deceased, and/or a child victim has been abducted or subjected to sexual or sadistic treatment; where an explosive has been used; or where the murder was committed for gain. ${ }^{38}$ Each of these features clearly reveals that more harm has been caused or threatened beyond the loss of a life. Similarly, in relation to non-fatal offences of personal violence, the Sentencing Guidelines Council stressed that harm is a crucial indicator of offence gravity - the seriousness of the offence... is determined by assessing the culpability of the offender and the harm caused, intended or reasonably foreseeable. ${ }^{39}$ Evidence can be admitted from medical and psychiatric experts of the harm caused through such offences, but simple logic dictates that the courts will invariably get a more comprehensive picture of the harm, not just to the immediate (or primary) victim but also to relatives and friends, from victim impact statements.

\footnotetext{
${ }^{37}$ However, as Edwards has pointed out, there was no attempt to discern the nature of the relationship between the 'public interest' and the interests of the victim: I Edwards, 'The Place of Victims' Preferences in the Sentencing of 'Their' Offenders' [2002] Crim LR 689.

${ }^{38}$ Criminal Justice Act 2003, Sch 21, paras 4-5.

${ }^{39}$ Sentencing Guidelines Council, Assault and other offences against the person: Definitive Guideline, (2008), cl 5. Other relevant statements in the Guideline include:- "The use of a weapon.... or part of the body (such as the head or other body part which may be equipped to inflict harm or greater harm...) will usually increase the seriousness...", (cl 22 - emphasis added).
} 
Evidence of a greater willingness on the part of the Court of Appeal to give particular consideration to the emotional effects of victim harm in cases of domestic burglary is apparent from the remarks of Lord Phillips LCJ in the recent case of $R v$ Saw \& Ors. ${ }^{40}$ The focus of his remarks was very much directed towards the nature of the risk and the adverse consequences that an offender may produce when committing burglary, whether these are intentional, or not. Such effects relate not only to the emotional consequences of material loss, but also to the aggravating impact of the severe shock that victims often experience, especially the elderly, when intruders are known to be present, as well as its aftermath.

In particular, the Court thought it unhelpful to compartmentalise the aggravating features of the offence in such cases into high or medium risk, or proceed on the basis that the appropriate sentence was a matter of aggregating such factors, as if it were 'some kind of hypothetical, quasimathematical calculation. ${ }^{, 41}$ Although specific guidance was clearly necessary on the 'objective' impact of high and low risk factors for reasons of consistency of approach, sentencers should be free to address the realities of each case before them. In this, the Court appeared to accept the need for some adjustment in the balance of the penal equation towards the victim through more specific recognition of the harmful emotional effects of burglary, as against the state's retributive concerns for consistency and proportionality or indeed the offender's interest in construing offence seriousness as an accurate reflection of culpability.

It may be argued that, in rejecting a formulaic approach towards calculating victim impact, the Court was implicitly recognising the need for sentencing discretion to take greater account of the state's obligation to the victim, and to the wider community, and, hence, to reflect the harmful psychological impact of burglary. Taken alone, cases such as Saw cannot be presumed to suggest a trend towards the sentencing process engaging with the issue of victim harm in a more participative sense. However, as with cases of murder and

\footnotetext{
${ }^{40}$ [2009] EWCA Crim 1.

${ }^{41}$ Ibid, [20].
} 
personal violence, it suggests that the emotional consequences of victim harm is achieving more prominence as an indicator of offence seriousness. Accordingly, the need to take more explicit and effective account of it when sentencing for domestic burglary should be seen as a move in the right direction.

\section{The Impact of Shifting Parameters}

Just as the courts and policymakers have expanded the concept of criminal responsibility, there has been a parallel acknowledgement of the need to modify existing procedures to give the victim some means of participation. We suggest that there are four major factors that have come to exert pressure on the state / offender dichotomy that lies at the core of the adversarial conflict. These are: (1) evolving standards for victims in human rights law; (2) emergent participatory norms in international criminal justice; (3) the rise of 'therapeutic jurisprudence'; and (4) the apparent collapse of the public / private divide within sentencing and penal policy.

As we proceed to argue, it is the cumulative effect of these factors which, in our opinion, indicates a change, or softening, in the resistance against allowing greater expression of victim impact in sentencing. In particular, improving access to justice for victims has not only reflected developing trends in human rights and international criminal justice norms, but has also been balanced by a much greater recognition of the need for accountability. In other words, there is a broader acceptance that trial justice really does need to engage with victims' needs in a positive sense, and can no longer marginalise them for reasons of retributive ideology, or the exigencies of the adversarial contest.

1) Evolving standards for victims in human rights law

Although international instruments now require the interests of victims to be taken into account in a variety of ways, such standards tend to eschew 
stipulating specific requirements concerning the role they ought to play in criminal proceedings. Even if many soft law instruments make some reference to the inherent value of participation, the language adopted by some of them tends to be vague and non-prescriptive. For example, Principle 6(b) of the UN Victims' Declaration provides that the judicial process should allow 'the views and concerns of victims to be presented and considered at appropriate stages of the proceedings where their personal interests are affected, without prejudice to the accused.'

There has been only one occasion to date where the issue of victim participation in sentencing has arisen before the European Court of Human Rights. In McCourt v United Kingdom, ${ }^{42}$ the mother of a murder victim complained that the failure of the state to allow her to participate in the sentencing process constituted a violation of her right to privacy and family life under Article 8 of the Convention. Rejecting her complaint, the Commission found that the failure of the United Kingdom sentencing framework to provide a participatory mechanism did not reveal any lack of respect for her right to family life. ${ }^{43}$ In the Commission's view, those interests had been sufficiently protected when the Parole Board considered the question of early release. The decision was unsurprising, since the European Court of Human Rights and the Commission have traditionally shied away from laying down specific procedural requirements in cases concerned with domestic sentencing procedures. However, the Strasbourg Court itself is not averse to hearing the views of victims in their capacities as third parties. In $T$ and $V \mathrm{v}$ United Kingdom, ${ }^{44}$ an application brought by those convicted of the murder of toddler Jamie Bulger, the parents of the victim were permitted to be present at the hearing and to make representations to the Court. Although the Strasbourg Court stopped well short of stipulating that this ought to be a requirement vis-

\footnotetext{
${ }^{42}$ App No 20433/92, 2 December 1992. Note, however, that the Court did highlight the fact that victims' opinions should be taken note of in the United Kingdom when the Parole Board decides on whether to grant early release.

${ }^{43}$ The Commission also rejected her complaint that denial of bereavement damages by the State also contravened Art 8.

${ }^{44}$ (1999) 30 EHRR 121.
} 
à-vis the domestic criminal process, Rock cites the toddler's mother as saying that it was a 'magnificent gesture' that she had been heard in this way since she had been precluded from doing so domestically. ${ }^{45}$

Nonetheless, it is unlikely that the Strasbourg Court will recognise a specific right for victims to participate in the sentencing process in the near future. It is perhaps more likely that the Court will continue steer a wide berth for some years to come since awkward conflicts may arise with the defendant's right to a fair and impartial hearing under Article 6(1) ${ }^{46}$ However, in the longer term, it is equally conceivable that some form of participatory right may emerge as Member States continue to make provision for it within domestic criminal law. John Jackson has argued that the jurisprudence from Strasbourg in recent years has effected a shift in the way we tend to categorise systems according to the adversarial or inquisitorial spectrum, arguing instead that the Court has developed a new model of proof that is better characterised as 'participatory' than as 'adversarial' or 'inquisitorial'. ${ }^{47}$ However, even if any participatory rights do emerge in future years, it is likely these would be limited in nature. It is difficult to conceive the Court advocating the more radical approach adopted in many parts of the USA which allows victims to make specific demands as to the length or type of sentence to be imposed. ${ }^{48}$

It is not only the Strasbourg organs which have become increasingly receptive to the concept of victim participation. Article 3 of the EU Framework Decision requires each Member State to safeguard the possibility for victims to be heard during proceedings and to supply evidence, and to take appropriate measures to ensure that its authorities question victims only insofar as

\footnotetext{
${ }^{45}$ P Rock, Constructing Victims' Rights: The Home Office, New Labour and Victims (Oxford: Clarendon Press, 2004), 254.

${ }^{46}$ See further F Leverick, 'What has the ECHR done for victims?' 11 IRV 177, 193.

$47 \mathrm{~J}$ Jackson, 'The Effect of Human Rights on Criminal Evidentiary Processes: Towards Convergence, Divergence or Realignment?' (2005) 68 MLR 737.

${ }^{48}$ B Emmerson and A Ashworth, Human Rights and Criminal Justice (London: Sweet \& Maxwell, 2001), 18-78. Indeed, they further suggest that any such statement could infringe the accused's right to an impartial hearing under Art 6 .
} 
necessary for the purpose of criminal proceedings. ${ }^{49}$ Though the language adopted is imprecise, the requirements of the Framework Decision are of particular significance since they are legally binding on all Member States. Article 3 was one of the provisions which lay at the core of the recent decision of the European Court of Justice in the case of Pupino, ${ }^{50}$ where an Italian court refused to order a pre-trial examination for eight young child witnesses in a cruelty case brought against their teacher. The European Court of Justice held that the Framework Decision 'must be interpreted as meaning that the national court must be able to authorise young children, who, as in this case, claim to have been victims of maltreatment, to give their testimony in accordance with arrangements allowing those children to be guaranteed an appropriate level of protection, for example, outside the trial and before it takes place. ${ }^{51}$ The Italian court was therefore under an obligation to interpret the terms of the Criminal Code 'in the light of the wording and purpose of the Framework Decision.'

While the Pupino decision was primarily concerned with the need to protect vulnerable witnesses rather than to enable the effective participation of victims generally, its relevance to the VFS should not be overlooked. The European Court of Justice has signalled that its days of sidestepping thorny questions of domestic criminal procedure are drawing to an end, and no Member State can consider itself exempt from the requirement that victims should be 'heard'. This will inevitably heighten the pre-existing tensions within the adversarial system. The extent to which the adversarial paradigm can effectively accommodate third party participatory rights is inherently limited, but the government might argue that the VFS represents one way of achieving this. Only time will tell whether that will be sufficient; future questions may well arise as to the overall effectiveness of the mechanism given that it is unavailable to the vast majority of crime victims. ${ }^{52}$ Whilst the construction of any imminent right to participate in sentencing might seem unlikely, it should

\footnotetext{
${ }^{49}$ O.J. L 82, 22.03.2001.

5016 June 2005, in Case C-105/03.

${ }^{51} \mathrm{lbid}$, para 61.

${ }^{52}$ The scheme is only available to certain victims in homicide cases - see discussion below.
} 
be borne in mind that few would have foreseen the somewhat radical terms of the Pupino decision.

\section{2) Emergent participatory norms in international criminal justice}

As in human rights law, the formulation of new rules of procedure and evidence in international criminal justice has been seen by some as indicators of an emergent consensus on the types of values and rights that should lie at the forefront of the criminal justice system. ${ }^{53}$ Although international trials deal with crimes which have been committed in a different social context and which are of a different magnitude from those typically encountered domestically, valuable lessons can still be learnt. There is, in particular, one common factor which justifies comparison. This is the need for the criminal process to engage with all those who are directly affected by trial justice, and by the wider audience which, in the case of international crimes, lies beyond territorial or state boundaries. Whether committed within or beyond such boundaries, the punishment of criminalised behaviours can only draw legitimacy if the kind of accountability established by the trial has a collective dimension. It is easier to see this where international trials are concerned because communities, racial or religious groups, and states appear more directly implicated. However, as it stands, international trial justice is constrained to produce 'truths' largely founded on individual accountability and struggles, to engage with the nature of the collective reality of what took place and its consequences. This is also the case in domestic criminal justice, except here, while the greater focus on individual accountability is obvious, penal policy is more duplicitous in

\footnotetext{
${ }^{53}$ The discussion here is restricted to the sentencing practices of the UN International Tribunals for the Former Yugoslavia and Rwanda (ICTY and ICTR, respectively), and the International Criminal Court (ICC). However, it should be borne in mind that their respective foundation instruments reflect distinct compromises between the procedural traditions of adversarial and inquisitorial trial. Some commentators argue that there has been considerable procedural 'drift' away from adversarialism towards the more blended normative paradigm of the ICC; see R Vogler, A World View of Criminal Justice (Aldershot: Ashgate, 2005), ch 14.
} 
asserting an engagement with victims and community, yet denying it in practice.

One of the most striking victim-related developments on the international platform has been the degree to which victims are able to participate at the International Criminal Court. Although the regime is considered to be progressive by most commentators, ${ }^{54}$ it should be borne in mind that the potential scope for victim participation is much broader than is the case in the normal domestic context, irrespective of whether the form of trial is adversarial or inquisitorial. This is partly because the ICC's procedural innovations include pre-trial rights for victims dealing with investigatory and jurisdictional matters peculiar to the Court's remit. ${ }^{55}$ Nevertheless, it is certainly true to say that the ICC trial process engages with victims' 'interests' to a much greater extent than most domestic systems of criminal justice in the developed world.

Much attention has been devoted by the Trial Chambers of the ICTY/ICTR to the clarification of issues relating to the protection of witnesses and their anonymity. ${ }^{56}$ Article $20(1)$ of the ICTY Statute, ${ }^{57}$ which governs the

\footnotetext{
${ }^{54}$ See eg S Zappalà, Human Rights in International Criminal Proceedings (Oxford: Oxford University Press, 2003); G Mekjian and M Varughese, 'Hearing the victim's voice: analysis of victims' advocate participation in the trial proceeding of the International Criminal Court' (2005) 17 Pace Intl L Rev 1; J Doak, 'Victims in the Criminal Process: An analysis of recent trends in regional and international tribunals' (2003) 23 LS 1.

${ }^{55}$ Article 15(3), ICC Statute permits victims to make representations to the Pre-Trial Chamber with respect to any request made by the Prosecutor to proceed with an investigation. Article 19(3) provides that victims may submit observations to the Court with regard to proceedings relating to jurisdiction and admissibility. Further, by virtue of Article 53(1)(c), the Prosecutor may conclude, despite having taken the gravity of the crime and the interests of victims into account, that an investigation would not serve the interests of justice. In such circumstances the Prosecutor must inform the Pre-Trial Chamber and the State making a referral or the Security Council (as appropriate) of his or her conclusion and the reasons for it; Article 54(2). See generally, Section III, Victims and Witnesses, ICC Rules of Procedure and Evidence.

${ }^{56}$ See Prosecutor $v$ Tadic (Case No. IT-94-I-T), Decision on the Prosecutor's Motion for Protective Measures for Victims and Witnesses, 10 August 1995, paras. 62-6; Prosecutor $v$ Blaskic (Case No. IT-95-14), Decision on the Application of the Prosecutor dated 17 Oct.1996 requesting Protective Measures for Victims and Witnesses, 5 November 1996, para. 41. For
} 
commencement and conduct of trial proceedings, requires Trial Chambers to ensure that they are conducted expeditiously in accordance with the rules of procedure and evidence, with due regard for the protection of victims and witnesses. Article $22^{58}$ goes on to provide that the ICTY 'shall provide in its rules of procedure and evidence for the protection of victims and witnesses'. Such protection measures shall include, but shall not be limited to, the conduct of in camera proceedings and the protection of the victim's identity. There has, however, been considerable criticism regarding the lack of any comprehensive witness protection programme. In consequence, a Victims and Witnesses Unit for the ICTY was established under Rule 34, but this encountered practical difficulties in obtaining improvements ${ }^{59}$ which have had a significant impact on the trial process. The ICC Statute, on the other hand, specifically provides for the creation of a Victims and Witnesses Unit within the Registry that is mandated to provide (in consultation with the Prosecutor's Office) protective measures and security arrangements, counselling and other appropriate assistance for witnesses, victims appearing before the Court and others who may be at risk because of such testimony. ${ }^{60}$

As regards the trial proper, Article 68 of the ICC Statute is especially significant. ${ }^{61}$ It provides a far more detailed account of the nature of victim and

criticism see the debate between Christine Chinkin and Monroe Leigh in vols 90 / 91 of the American Journal of International Law.

${ }^{57}$ Article 19(1), ICTR Statute.

${ }^{58}$ Article 21, ICTR Statute

59 These include problems relating to the lack of any definition of witness and when such a person might qualify for protection from the Unit, and the fact that contact is primarily with the Registry whereas the relationship of victims and witnesses with the Tribunal prior to trial is mainly through the Prosecution.

${ }^{60}$ Article 43(6), ICC Statute. The position of victims is also strengthened by the creation of a Trust Fund to be administered according to criteria to be determined by the Assembly of State Parties. The Fund is established for the benefit of victims of crimes within the Court's jurisdiction and their families. Property collected through fines and forfeiture may be transferred to the Fund by order of the Court; Article 79, ICC Statute.

${ }^{61}$ Rule 86, ICC RPE contains a general injunction to the Trial Chamber and other Court organs when performing their functions under the Statute or Rules to take into account the 
witness protection ${ }^{62}$ and their participation in the proceedings than does Article 22 of the ICTY Statute. ${ }^{63}$ For example, Article 68(1) provides that the ICC 'shall take appropriate measures to protect the safety, physical and psychological well-being, dignity and privacy of victims and witnesses' and imposes obligations in this respect upon the Prosecutor. Significantly, the provision goes on to state that the measures taken are not to be prejudicial to or inconsistent with rights of the accused and a fair and impartial trial. This injunction is repeated in Article 68(3), which provides that the Court has the discretion to permit the views of victims and their concerns to be presented and considered at whatever stages in the proceedings it thinks fit, where the personal interests of victims are affected.

The detailed implementation of these provisions is to be found in the ICC Rules of Procedure and Evidence ${ }^{64}$ but, notwithstanding the procedural injunctions contained therein, there is nothing that obliges the Court to admit relevant victim evidence. Read in conjunction with Rule 145, which deals with the determination of sentence, the ICC provisions concerned with victims do not provide for their unconditional participation in any stage of the proceedings.

Article 68 is conditional in several aspects. For example, the decision as to what constitutes 'the personal interests of the victims' is left to the Court's discretion, as is the decision whether to admit the victims' views and concerns at all. Article 68(3) simply mandates the Court to 'permit their views to be presented and considered at stages of the proceedings determined to be appropriate by the Court' and then goes on to qualify that possibility further by adding that any such presentation and admission must be 'in a manner which is not prejudicial to or inconsistent with the rights of the accused and a fair

needs of all victims and witnesses as directed by Article 68 especially children, elderly persons, persons with disabilities and victims of sexual or gender violence.

${ }^{62}$ See Rule 87, ICC RPE for details of their procedural implementation.

${ }^{63}$ Article 21, ICTR Statute.

${ }^{64}$ Section III, Subsection 3 Participation of victims in the proceedings, Rules 89-93. 
and impartial trial. ${ }^{65}$ Rule 145(1)(C) merely obliges the Court to 'give consideration' to (inter alia) the harm caused to victims and their families. There is no right for them to lodge a victim impact statement which must be taken into account in fixing the sentence. ${ }^{66}$

In short, the ICC Trial Chamber's obligations do not extend beyond immediate victims within the jurisdiction of the court and their families ${ }^{67}$ to take on board

${ }^{65}$ This is a necessary discretion to maintain balance between the competing rights of the parties.

${ }^{66}$ Further elaboration of the appropriate parameters for victim participation was recently provided by the ICC Appeals Chamber which confirmed that the harm suffered by victims within the scope of Rule 85 must be personal, although it does not necessarily have to be direct. Significantly, the Prosecutor resisted the idea put forward by victims' representatives that they had a personal interest in the establishment of the charges on the basis that this served to confuse the victims' role with that of the Prosecutor. The Appeals Chamber also determined that the harm and personal interests of victims in relation to their participation in the trial under Article 68 (3) ICC Statute must be linked to the charges against the accused. Consequently, once recognised as a victim under Rule 85, pursuant to Article 68(3), victims will first need to establish their personal interest in the trial before they are permitted to express their views and concerns (subject to the Court's discretion), although this must not prejudice or be inconsistent with the rights of the accused and a fair and impartial trial. Finally, the Appeals Chamber decided that victims may lead evidence pertaining to the guilt or innocence of the accused and to challenge the admissibility of evidence in so far as this fulfils the purposes of the trial, subject to a number of procedural safeguards. However, this must take place within the parameters set by the charges in the indictment, since these establish the issues to be determined and thereby limit the Trial Chamber's authority; Judgment on the appeals of The Prosecutor and The Defence against Trial Chamber l's Decision on Victim Participation of 18 January 2008; Situation in the Democratic Republic of Congo, Prosecutor $v$ Thomas Lubanga Dylio (Case No ICC-01/04-01/06 OA 9 A 10), 11 July 2008.

${ }^{67}$ Principle 2 of the UN Victims Declaration makes clear that a person may be considered a victim, regardless of whether the perpetrator is identified, apprehended, prosecuted or convicted and regardless of the familial relationship between the perpetrator and the victim. This principle further clarifies that the concept of victim 'also includes, where appropriate, the immediate family or dependants of the direct victim and persons who have suffered harm in intervening to assist victims in distress or to prevent victimization'. Unfortunately, such clarification was not included by the drafters of the ICC provisions. See further commentary by Amnesty International, The International Criminal Court: Ensuring an Effective Role for Victims (AI Index: IOR 40/10/99). The fact that there are multiple victims may be taken into 
the feelings and concerns of 'significant others' within victim communities. No attempt has been to provide mechanisms to address what these wider concerns might be and how the Court might engage with them, or whether what is proposed has any sort of moral legitimacy in terms of the wider community. Furthermore, there is no apparent indication, either in any rationale discernable from the foundation instruments or any procedural mechanisms, whether what victims are allowed to put forward and its admission subject to the Court's discretion might (or should) contain information along these lines. Again, the concerns of victims and victim communities appear to receive symbolic rather than actual attention. ${ }^{68}$

Whilst Zappalà is undoubtedly correct in suggesting that '... in the ICC Statute an attempt has been made to increase the procedural rights for victims and expand them to the procedural dimension, ${ }^{69}$ arguably such expansion has been more symbolic than concrete in its effects and has had little (if any) impact in addressing the fundamental philosophical and structural weaknesses affecting international criminal trials and sentencing. ${ }^{70}$

More than symbolism is promised by Article 75 of the ICC Statute which enjoins the Court to establish principles relating to reparations to (or in respect

account as an aggravating factor in the determination of sentence; Rule 145(2)(b)(iv) of the ICC Rules of Procedure and Evidence.

${ }^{68}$ In this sense, therefore, it may be argued that the rights provided for are what Ashworth (1993) might describe as 'service rights' rather than 'procedural rights'; A. Ashworth, 'Some Doubts about Restorative Justice' (1993) 4 Crim LF 277. A distinction may be drawn in the characterisation of so-called 'procedural rights' between those rights that allow for the possibility of some form of participation by victims, and those rights that mandate that possibility.

${ }^{69}$ Zappalà, above n 54. Whilst Zappalà does acknowledge certain practical drawbacks pertaining to the greater procedural participation possible for victims under the ICC regime (at p 232).

${ }^{70}$ For a summary; see R Henham 'Some Issues for Sentencing in the International Criminal Court' (2003) 52 ICLQ 81. 
of) victims to include restitution, compensation ${ }^{71}$ and rehabilitation. It is clear, however, that reparations is employed as a concept which includes something analogous to civil damages and the restitution of property, or what Retzinger and Scheff ${ }^{72}$ refer to as 'material reparation' in the context of restorative justice. $^{73}$ Of much greater importance ${ }^{74}$ is the potential for 'symbolic reparation' which, as Johnstone suggests, ${ }^{75}$ refers to a less visible process whereby the social bond between offenders and victims is repaired and restored through a process where shame and related emotions are evoked and acknowledged by the participants. It is equally apparent that the sense in which 'rehabilitation' is used in Article 75 suggests a narrower conceptualisation that envisages material improvements for victims and communities as a necessary precursor to any kind of symbolic healing.

The implications of these developments for procedural justice and victims' rights are profound. Although there has undoubtedly been increased recognition for victims in international trial processes, for these aspirations to become reality requires something more than an increased potential for change. In substantive and procedural terms this involves moving beyond the possibility of increased victim participation within the current normative

\footnotetext{
${ }^{71}$ The issue of compensation for victims in relation to the ICTY was the subject of a working group; see further Eighth ICTY Annual Report, UN doc. A/56/352, 17 September 2001.

${ }^{72} \mathrm{~S}$ Retzinger and T Scheff, 'Strategy for Community Conferences: Emotions and Social Bonds' in B Galaway and J Hudson (eds) Restorative Justice: International Perspectives (Monsey, NY: Criminal Justice Press, 1996), at 315.

${ }^{73}$ In restorative terms, material reparation suggests a specified settlement between the parties, something not contemplated by Article 75, despite the fact that, according to Article 75(3), the Court has a discretion to invite representations from 'the convicted person, victims, other interested persons or interested States which it is obliged to take account of before making any order.

${ }^{74}$ As Zedner suggests, in practice such a dichotomy may be exaggerated. Mediation, for example, may lead to practical actions making good damage done and, therefore, its impact is also material; L Zedner 'Reparation and Retribution: Are they Reconcilable?' (1994) 57 MLR 226.

${ }^{75} \mathrm{G}$ Johnstone, Restorative Justice: ideas, values, debates (Cullompton: Willan Publishing, 2002), 117.
} 
framework (welcome as this may be) and moving towards a model of proactive engagement for victims.

Similarly, for England and Wales, the main lesson to be learned from developments on the international stage is that the tensions and obfuscation caused by trying to accommodate victims' 'interests' through such mechanisms as the victims' advocates scheme, particularly in the sentencing context, will not be dissipated unless there is greater clarity about what the purposes for victim engagement are and what it is meant to achieve. Arguably, as is the case with the ICC, the key lies in ensuring that:

- The rights given to victims are 'real' in the sense that their 'interests' ${ }^{, 76}$ are actually factored into sentencing decisions.

- Sentencing judges are given the normative flexibility to achieve this.

- A positive duty is placed upon the Court to ensure that victims' rights do not jeopardise the rights of the accused or threaten a fair and impartial trial process. $^{77}$

- An ideological shift takes place to underpin penal policy thereby allowing trials (and sentencing in particular) to maximise the normative flexibility to pursue more restorative outcomes for victims. Such an approach will make it easier for courts to reach beyond the immediate families of victims to take account of 'interests' within the wider community when sentencing for serious crimes.

\footnotetext{
${ }^{76}$ Clearly, the nature and scope of such 'interests' and the purpose of victim participation need to be very carefully defined. One of the most important issues to be resolved is how these purposes might be linked to other sentencing aims and their achievement in concrete cases.

${ }^{77}$ In this the state should assume a greater responsibility for ensuring that the trial fulfils the legitimate expectations of its citizens for 'justice'.
} 
Recent years have witnessed a growing interest in the application of therapeutic jurisprudence (TJ) - particularly in the United States and Canada. TJ began life in the mid-1990's as a theory developed by Wexler and Winick. ${ }^{78}$ It postulates the psychological and emotional consequences of the legal process upon its primary stakeholders, and views the legal process as a social agent which is capable of both enhancing and diminishing one's emotional life and sense of psychological well-being. ${ }^{79}$ Whilst the field is still relatively underdeveloped and has been subject to criticism, ${ }^{80}$ it continues to grow rapidly. Today, TJ discourse is interdisciplinary in nature, and seeks to apply key aspects of psychological literature to legal procedures. Indeed, the field's rapid expansion has been propelled in part by an explosion in thematic research focusing on the role of emotions in both the biological and social sciences. ${ }^{81}$ Central to this 'emotions' discourse is the idea that either oral or written accounts delivered in free narrative form can help reduce feelings of anger, anxiety and depression; ${ }^{82}$ bolster self-confidence; ${ }^{83}$ and even improve physical health. ${ }^{84}$

${ }^{78}$ DB Wexler and BJ Winick, Law in a Therapeutic Key: Developments in Therapeutic Jurisprudence (Durham, NC: Carolina Academic Press, 1996).

79 D.B. Wexler, 'Therapeutic jurisprudence forum: practicing therapeutic jurisprudence: psycholegal soft spots and strategies' (1998) 67 Rev Jur UPR 317.

${ }^{80}$ See eg C Slobogin, 'Therapeutic Jurisprudence: Five Dilemmas to Ponder' (1995) 1 Psychol Pub Pol'y \& L 193, who contends that TJ has not provided a satisfactory means of balancing therapeutic values with other goals in the legal process.

${ }^{81}$ L Sherman, 'Reason For Emotion: Reinventing Justice With Theories, Innovations, And Research-The American Society Of Criminology 2002 Presidential Address' (2003) 41 Crim 1.

${ }^{82}$ See eg T Orbuch, J Harvey, S Davis, et al. 'Account-Making and Confiding as Acts of Meaning in Response to Sexual Assault', (1994) $9 \mathrm{~J}$ Fam Violence 249; L Mills, 'Killing her softly: Intimate abuse and the violence of state intervention' (1999) 113 Harvard L Rev 550.

$83 \mathrm{~J}$ Kellas and $\mathrm{V}$ Manusov, 'What's in a story? The relationship between narrative completeness and adjustment to relationship dissolution' (2003) $20 \mathrm{~J}$ Soc Pers Relat 285.

${ }^{84} \mathrm{RD}$ Enright and RP Fitzgibbons, Helping Clients Forgive: An empirical guide for resolving anger and restoring hope (Washington, DC: APA Books, 2000). 
The exponential growth of TJ carries potentially major implications for the criminal justice system, some of which are already evident. Some of these are offender-based. Petrucci describes how certain crime prevention programmes in the United States have adopted cognitive behaviour techniques to help offenders develop empathy toward victims. ${ }^{85}$ Other aspects of TJ are more community-orientated or victim-orientated in nature: the recent proliferation in restorative justice and community courts are two such examples. ${ }^{86}$ However, much of TJ's early impact has been on the fringes of the system, with mainstream prosecution, trial and sentencing processes remaining largely untouched by any therapeutic concern. ${ }^{87}$ This should not surprise us: it is not at all clear precisely how the therapeutic goal fits into the much more deeply ingrained values that underpin the criminal justice system. Proponents of a more therapeutic approach to criminal justice contend that forgiveness, reconciliation, restoration, and emotional closure ought to feature alongside (or as alternatives to) the largely punitive objectives that have traditionally characterised western criminal justice systems. ${ }^{88}$

Victims of crime are likely to be the stakeholders most likely to benefit from the ascendancy of TJ. The effects of victimisation - particularly from serious crime - are comprehensively documented, though it is widely recognised that the effects of victimisation vary considerably. The impact of crime will, of

${ }^{85}$ CJ Petrucci, 'Apology in the Criminal Justice Setting; Evidence for Including Apology as Additional Component in the Legal System.' (2002) 4 Behavioral Science and the Law 337.

${ }^{86}$ See respectively D Rottman and P Casey, 'Therapeutic Jurisprudence and the Emergence of Problem-Solving Courts' (2000) National Institute of Justice Journal, July, 12-19; RF Schopp, 'Integrating Restorative Justice and Therapeutic Jurisprudence' (1999) 67 Rev Jur UPR 665.

${ }^{87}$ See, however, the comments of Sully $\mathrm{J}$ in the New South Wales Court of Criminal Appeal in $R \vee F D ; R \vee F D ; R \vee J D$ (2006) 160 A Crim $\mathrm{R} 392$, where the function of victim impact statements to provide an 'emotional catharsis' for victims was explicitly recognised. See further T Kirchengast, 'Sentencing Law and the 'Emotional Catharsis' of Victim's Rights in NSW Homicide Cases' (2008) 30 Syd L Rev 615.

${ }^{88}$ See eg E Erez, 'Victim Voice, Impact Statements and Sentencing: Integrating Restorative Justice and Therapeutic Jurisprudence Principles in Adversarial Proceedings' (2004) 40 Crim LB 483. 
course, vary according to the characteristics of individual victims; some victims will be seriously traumatised by what may appear to be a relatively trivial offence, whereas others may be able to find closure and healing soon after falling victim to a serious offence. ${ }^{89}$ However, often crime will carry with it some degree of emotional distress for a time after the offence, with victims often experiencing a loss of confidence or living in a state of fear of a repeated attack. ${ }^{90}$

One of the primary means to find closure and overcome the trauma and anxieties caused by crime is through account-making. Indeed, contemporary psychotherapy and counselling practice is founded on the premise that externalising traumatic experiences through verbalisation constitutes an effective coping mechanism for many people facing upheavals from major lifechanging events, including violent crime. ${ }^{91}$ It follows that if victims are given an outlet through which they can channel their emotions, they may be able to recover from the effects of victimisation more readily. Through verbally representing past memories of trauma within a grander 'life narrative', victims are better equipped to find closure and move on. ${ }^{92}$

${ }^{89} \mathrm{~J}$ Shapland and M Hall, 'What do we know about the effect of crime on victims?' (2007) 14 IRV 175.

${ }^{90}$ For an excellent summary of relevant empirical studies, see Shapland and Hall, ibid. See also L Zedner and C Hoyle, 'Victims, Victimization, and the Criminal Process' in M. Maguire, R Morgan \& R Reiner (eds), The Oxford Handbook of Criminology (Oxford: Oxford University Press, $3^{\text {rd }}$ ed, 2007).

${ }^{91}$ See eg JW Pennebaker, Opening up: The Healing Power of Confiding in Others (New York: W Morrow, 1990); M White and D Epston, Narrative Means to Therapeutic Ends, London: WW Norton \& Company, 1990); T Orbuch, 'People's Accounts Count: The Sociology of Accounts' (1997) 23 Annual Review of Sociology 455. On overcoming particular problems facing homicide victims, see J Kenney, 'Gender Roles and Grief Cycles: Observations of Models of Grief and Coping in Homicide Survivors' (2003) 10 IRV 19.

${ }^{92}$ M J Horowitz, Stress Response Syndromes (New York: Jason Aronson, $2^{\text {nd }}$ ed, 1986). See generally K Harber and J Pennebaker, 'Overcoming Traumatic Memories' in S Christianson (ed.), The Handbook of Emotion and Memory: Research and Theory (London: Lawrence Erlbaum Associates, 1992). 
Of course, the opportunity to give free accounts of such events is extremely curtailed within the formal criminal justice system. From prosecution through to sentencing and beyond, the criminal process serves to stifle free narrative and restricts the ability of victims to express themselves freely. At first sight, this may seem ironic, since the role of story-telling in the criminal trial was identified long before the ascendancy of therapeutic jurisprudence. Just as proponents of therapeutic jurisprudence advance the thesis that human beings need a coherent story frame to make sense of past experiences and overcome related emotional traumas, story-telling theory states that courts arrive at decisions by constructing stories based around the way the evidence is presented to them. ${ }^{93}$ Stories are used to enable the jury to identify the central action in the alleged crime; to make empirical connections among evidential elements based on that storyline; and to then interpret and evaluate those connections for internal consistency, completeness, and for their collective implications for the central action. ${ }^{94}$ However, in common law trial and sentencing processes, it is the advocates, rather than the victims in their capacity as witnesses, who assume the roles of story-tellers. The adversarial system has a tendency to 'crush' the narratives of individuals, ${ }^{95}$ and, as Pizzi has stated, 'turns witnesses into weapons to be used against the other side., ${ }^{96}$ It is widely accepted that one of the primary goals of the advocate is to

${ }_{93}$ See further WL Bennet and M Feldman, Reconstructing Reality in the Courtroom (Brunswick: Rutgers University Press, 1981); N Pennington and R Hastie, 'The Story Model for Juror Decision Making' in R Hastie (ed), Inside the Juror: The Psychology of Juror Decision Making (Cambridge: Cambridge University Press, 1993).

${ }^{94}$ Bennet and Feldman, ibid at 67.

${ }^{95} \mathrm{~J}$ Braithwaite, 'Building Legitimacy Through Restorative Justice' in T Tyler (ed), Legitimacy and Criminal Justice: International Perspectives (New York: Russell Sage Foundation, 2007).

${ }^{96}$ W Pizzi, Trials Without Truth (New York: New York University Press, 1999), at 197. An interesting paradox, however, can be found in the case of professional expert witnesses. Concerns have been expressed that their testimony is incapable of being effectively challenged by the advocates who are not themselves familiar with the methodological basis for the expertise. To this end, the rules on the examination of experts were subject to a fundamental overhaul in Part 35 of the Criminal Procedure Rules (2005), which stipulates that the expert's duty to the court now 'overrides' any duty to the instructing party (CPR r. 35.3(2)). See further B Thompson, 'Watch this space' (2005) 155 NLJ 773-774; D Ormerod, 'Expert evidence: where now? What next?' (2006) 5 Arch. News 5-9. 
manipulate witness testimony in such a way that victory is made more likely, and the testimony must therefore be shaped to bring out its maximum adversarial effect. ${ }^{97}$ Indeed, a recent empirical study by Hall suggests that this is a prominent feature of criminal trials in England and Wales. ${ }^{98}$ Storytelling thus lies at the heart of the adversarial trial, except that the accounts are given by the advocates, and juries are invited to devise their own version of events based on those accounts. By contrast, victims have no opportunity to present their own account of past events, but are instead confined to answering questions within the parameters set down by the questioner. If proponents of therapeutic jurisprudence are correct, such a setting will necessarily limit the cathartic potential of the criminal process for the victim.

The adversarial setting appears to be inherently limited in its capacity to deliver the types of curative effects identified by proponents of therapeutic jurisprudence. For this to be accomplished, new channels of communication between the victim, offender and the court are needed in order for meaningful account-making to take place. Not only might this change be of some cathartic value in itself, but would also constitute an official acknowledgement that the stories of victims matter. However, by the same token, there is a danger in attaching the 'therapeutic' label to criminal justice initiatives which, while promoting 'participation' on paper, actually do very little in practice to encourage a form of participation that is both meaningful and effective in terms of catharsis. If we are serious about integrating a therapeutic agenda into criminal justice, we need to think in much more concrete terms about the ways in which participatory mechanisms are designed in order to reap a tangible sense of forgiveness, reconciliation and closure for victims of crime.

Although $\mathrm{TJ}$ offers a new and refreshing perspective on the potential emotional and cathartic benefits of victim participation, the pervasive influence of retributive justice and the adversarial paradigm still appear to pose significant obstacles to their realisation. It would be foolhardy to transform the

\footnotetext{
${ }^{97}$ W Pizzi, ibid.

${ }^{98}$ M Hall, Victims of Crime: Policy and practice in Criminal Justice (Cullompton: Willan, 2009), see esp. ch 6 .
} 
criminal justice system solely along therapeutic lines without giving due consideration to very real concerns among some commentators about the potential prejudice that such participation may entail. It is worth underlining that our arguments in this article our confined to bolstering the role of the victim at the sentencing stage of criminal proceedings. Special need for caution is needed within the trial itself, where the guilt of the accused remains an issue. In the pre-conviction phase of criminal proceedings, the status of the complainant 'victim' is somewhat uncertain prior to the determination of the accused's guilt. ${ }^{99}$

It is also suggested that much of the commentary concerning TJ has failed to propose any specific model for integrating the therapeutic agenda into contemporary forms of criminal process and sentencing. There has been little suggestion as to how the therapeutic goals might sit alongside (or compete with) a myriad of other criminal justice objectives, such as objective adjudication, the desirability of truth-finding, the preservation of the public interest, and the need to preserve fair trial rights. Indeed, one may well ask the question why a therapeutic agenda is necessary at all, given that immediate impact will be necessarily be limited to victims and offenders. The majority of witnesses are likely to have little or no personal interest in the therapeutic effects of the trial process. ${ }^{100}$ Nevertheless, the rapid growth of TJ within both legal and psychological discourse suggests that it is perhaps time to cease thinking of the pros and cons of victim participation in purely instrumentalist terms. Participatory rights may or may not assist the court in dispensing justice, but they may also empower victims through providing them with a means to channel their messages and stories to the offender, the court, and the wider community. ${ }^{101}$ Moreover, the growth of the discipline adds a

\footnotetext{
${ }^{99}$ See further J Doak, 'Victims' Rights in Criminal Trials: Prospects for Participation' (2005) 32 JLS 294.

${ }^{100}$ Some commentators, however, have argued that in time, restorative practices may come to percolate social relationships and wider society. See eg. D. Sullivan and L. Tifft, Restorative Justice: Healing the Foundations of Our Everyday Lives (Monsey, NY: Willow Tree Press, 2005).

${ }^{101}$ See eg J Roberts and E Erez, 'Communication in Sentencing: Exploring the Expressive
} 
powerful stimulus to our argument that important shifts are taking place in the normative parameters of criminal justice which favour greater victim participation.

\section{4) The erosion of the public / private divide in sentencing}

As discussed earlier, the need for criminal process to better engage with the emotional impact of crime on victims is becoming increasingly discernible with regard to recent developments in international criminal justice. Although by no means perfect, the ICC has responded to this need by providing a radically new normative framework for victims. Despite clear differences in the notion of 'penality' between international and domestic forms of criminal justice, there is no doubt that such international movements have been prompted by a gradual realisation that the future legitimacy of international trial justice depends on more concrete and relevant forms of engagement with victims and communities impacted by social conflict. Similarly, within domestic contexts, especially within transitional settings such as Northern Ireland, there is a need for the justificatory rhetoric of sentencing to connect more specifically with the interests and aspirations of victims and communities, and more broadly with the increasingly divergent views about the legitimacy of 'justice' within modern society. ${ }^{102}$

Of course, conflicting views about the legitimacy of trial justice is nothing new. Its roots often lie in cultural tensions about the kinds of behaviour criminalised by law and, more particularly, differences in penal ideology and how criminal justice should reflect the 'appropriate balance' between rights asserted by different social groups. The distinction between public and private interests in the criminal law is thus somewhat artificial, and has been so since its

Function of Victim Impact Statements' 10 IRV 223, proposing a 'communicative' model rather than an 'impact' model for the incorporation of victim statements at sentencing.

102 See further K McEvoy, 'Beyond Legalism: Towards a Thicker Understanding of Transitional Justice' (2007) 34 JLS 411. 
inception during the Middle Ages. ${ }^{103}$ Indeed, a closer look at the actual nature of individual crimes and torts suggests that it is not so easy to neatly separate the public from the private interests. Despite the state's appropriation of the criminal conflict over time, it remains clear that civil and criminal liability are each based on overlapping concepts of fault, recklessness and strict liability, with many crimes having their equivalent in the law of tort. ${ }^{104}$ In this sense, public and private wrongs may be conceived as variations along the same continuum of fault; ${ }^{105}$ indeed this theoretical blurring is already reflected in a number of ways on both the domestic and international platforms. If concepts such as 'harm,' 'reparation' and 'punishment' are viewed through a different lens, it may be that the sentencing objectives of the court could also take into account the restitutionary interests of the victim, without jeopardising the objectivity or denunciatory aspects of the penal system.

The key to this may lie in how the criminal process is able to respond to changing perceptions of 'fault' in the criminal law. If the concept of 'fault' remains firmly tied to establishing individual criminal responsibility, sentencing will accordingly remain rooted to notions of blame, censure and retributive justice. However, if the changing balance between public and private interests is thought of as a foundational shift in the social contract between citizen and state, then the criminal law and criminal process should reflect this through changed notions of responsibility. In other words, criminal justice can be conceived as moving back towards a more collective form of accountability for those whose behaviour is labelled as crime. In this sense, the changes in the balancing of interests within the criminal law and criminal process that are taking place reflect a recapturing of the shared morality by which communities accept the criminalization of certain behaviours, and how they should be punished. Hence, not only is the notion of 'victim' being broadened to focus

103 See further A Ashworth, 'Punishment and Compensation: Victims, Offenders and the State' (1986) 6 OJLS 86.

${ }^{104}$ A Goldstein, 'Defining The Role Of The Victim In Criminal Prosecution' (1982) 52 Miss LJ $515,530$.

${ }^{105}$ D Weisstub, 'Victims of Crime in the Criminal Justice System' in E Fattah (ed) From Crime Policy to Victim Policy (London: Macmillan, 1986), 206. 
more on the concept of harm than culpability, but also, the communitarian basis for the criminalization of certain actions and their consequences begin to assume a greater significance in the penal equation. Harm, it is submitted, should not be seen in purely objective terms, but should instead be related to victim and community perceptions of wrongdoing and the moral consequences of those judgments for those charged with delivering justice in the courts. In this way, the community becomes more directly responsible for the definition of harm and how to deal with its consequences through the criminal process.

To some extent, this trend towards a broader understanding of criminal harm is already discernible. As previously noted, conceptions of criminal responsibility within sentencing have expanded to take much closer account of the nature of the harm or loss suffered (or threatened) to the victim. This trend is even more marked when we consider the form of penalty that the criminal justice system is willing to impose. Since 1972 criminal courts have had the power to order an offender to pay a victim compensation for 'any personal injury, loss or damage resulting from the offence', ${ }^{106}$ and courts are now obliged to consider whether it would be desirable to make a compensation order and must give reasons for refusing to do so. ${ }^{107}$ Field and Roberts argue that a 'subtle but important shift' has taken place, whereby the criminal justice system is becoming increasingly geared 'toward a more interactive relationship between the individual rights of victims and their families on the one hand, and collective interests on the other.' ${ }^{108}$ This

\footnotetext{
${ }^{106}$ The court may make a compensation order, instead of, or in addition to, any other penal sanction. Where the offender has insufficient means to pay both, the court shall give preference to the compensation order (section 130(12) Powers of Criminal Courts (Sentencing) Act 2000). The powers were originally set out in Criminal Justice Act 1972.

${ }^{107}$ Powers of Criminal Courts (Sentencing) Act 2000, s 130. Section 130(4) of the Act states that compensation 'shall be of such amount as the court considers appropriate, having regard to any evidence and to any representations that are made by or on behalf of the accused or the prosecutor, the Court.'

108 S Field and P Roberts, 'Racism and Police Investigations: Individual Redress, Public Interests and Collective Change after the Race Relations (Amendment) Act 2000' (2002) 22 LS 493, 495. See also Fenwick, above n 33.
} 
relationship is also evidenced by the rapid ascent of restorative justice initiatives in recent years. Over the course of the past decade, such projects have gained a firm foothold in Britain and have been mainstreamed as the central response to youth offending in Northern Ireland. ${ }^{109}$

This shift towards the privatisation of criminal justice does not sit easily with the distinction traditionally drawn by the common law between public and private interests. However, it would now seem that such a neat separation is difficult to justify in logical terms. In view of the pace of recent developments, we should perhaps pause to consider whether the private interests of victims can be adequately encapsulated in purely monetary forms such as civil damages, criminal compensation orders and, indeed, state-based compensation for criminal injuries. As Walther explains:

'The variety of terms we encounter reflects the difficulty inherent in defining what 'making good' to the victim is actually about, and sheds light on the awkward, doctrinally unresolved standing of the victim's interests between the spheres of private and public law. This difficulty is easily obfuscated if we borrow a term from 'civil' or 'private' law and try to redefine it as an umbrella term for 'making amends' to a victim of crime. Both the terms 'restitution' and 'compensation' are too narrowly predefined by civil law to properly serve this purpose. Although the term 'reparation' also exists in civil law, it appears better suited for the umbrella function since, unlike 'restitution' and 'compensation', it does not per se predetermine the modalities of making good.' 110

Viewing reparation in this way, the task of ',making good' could be achieved through various non-pecuniary means. On the international platform, the concept of reparation for victims of abuse of power is generally

\footnotetext{
109 For an overview, see J Dignan, Understanding Victims and Restorative Justice (Maidenhead: McGraw-Hill / Open University Press, 2005), ch 4. See also D Roche, Accountability in Restorative Justice (Oxford: Oxford University Press, 2003), Ch 1.

110 S Walther, 'Reparation and Criminal Justice: Can they be integrated?' (1996) 30 Israel Law Review 316, 320.
} 
conceptualised in a much broader and more flexible way. Apologies, explanations, guarantees of non-repetition, and the uncovering of truth are examples of how wider and more communitarian forms of reparation have begun to penetrate our understanding of state crime and human rights abuses. $^{111}$ In drawing from these rapidly expanding discourses, a newly configured criminal justice system could distinguish itself from traditional doctrinal conceptions of compensation and restitution as developed by both the civil and criminal limbs of the common law. This more flexible concept of reparation could potentially address a much wider set of aims above and beyond either criminal compensation orders or the law of tort. Instead, the resolution of the victim / offender conflict would be reconceptualised as part of the wider public interest, since the community is made up of 'victims, potential victims and the fellow citizens of victims. ${ }^{112}$ Indeed, victims would not be the only beneficiaries of such an approach. The injection of a civil interest into the somewhat elusive concept of the 'public interest' could lend additional legitimacy to the outcome of the case, thereby benefiting the criminal justice system as a whole. By the same token, Weisstub also contends that the civil justice system could benefit from infusing itself with the symbolism of criminal sanctions, thereby showing itself to be 'consonant with public morality and conscience.'113

\section{The VAS / VFS in Context}

Although there may be signs of a re-balancing of the public/private interest towards victims, the rigidity of adversarial trial and the retributive justice model continue to act as significant obstacles to more comprehensive reform. Arguably, the prospects for victim participation and the development of restorative justice strategies are unlikely to be further advanced within the

\footnotetext{
111 See further Doak, above n 18, Ch6.

${ }^{112}$ Cavadino and Dignan, above n 11, p 237.

${ }^{113}$ Weisstub, above n 105, p 207.
} 
constraints imposed by proportionality and deserts-based ideology, ${ }^{114}$ Nevertheless, the VAS has been presented as a genuine attempt by the executive to confront this apparent impasse in the development of penal policy.

At first glance, it may appear that the national roll-out of the VFS broadly reflects the above-mentioned shifts in human rights discourse, international criminal justice, therapeutic jurisprudence, and changing dynamic in the relationship between individuals and the state. There may be a temptation to conclude that, through giving victims a 'voice' in the criminal justice system along the lines proposed by the Government, satisfaction rates and perceptions of legitimacy in the sentencing process would receive a much needed boost. The scheme was, after all, promoted in the following terms by the Lord Chancellor: ${ }^{115}$

'We want victims to be heard properly and fully in court... We want to give victims a voice directly in court. We want to end the culture of silence which can envelop victims and their families. We want to tear down that veil of silence - and let the voice of the victim be heard'.

However, Sweeting et al's evaluation of the VAS broadly confirmed what has been found elsewhere, ${ }^{116}$ that the impact statements seemed to have very little influence on sentencing, that they provided a modest degree of satisfaction to victims' families, and that they were not liked by some legal

\footnotetext{
${ }^{114}$ Furthermore, the fragmentation of process through the introduction of discrete structures for dealing with particular forms of offender or offending behaviour understandably does little to advance the cause of integration, either in theory or practice. As the Italian experience suggests, changes in structure and form without a corresponding re-evaluation in the overall purposes of prosecution, trial and sentence beyond a basic need to remedy procedural deficiency produce penal structures whose philosophical justifications are impossible to reconcile within the existing stated aims of punishment, and the legislative model which embodies them; R Henham and G Mannozzi, 'Victim Participation and Sentencing in England and Italy: A Legal and Policy Analysis' (2003) 11 Eur J Crime Cr L Cr J 278.

${ }^{115}$ Department of Constitutional Affairs, Hearing the Relatives of Murder and Manslaughter Victims (London: Department of Constitutional Affairs, 2005), at 4.

${ }^{116}$ See Hoyle et al, above n 27; Chalmers et al, above n 13.
} 
practitioners and judges. One particular problem with telling victims that they have been provided with a 'voice' is that victims will expect it to carry considerable weight in the sentencing decision. Under the VAS, like other forms of victim impact statement previously tested in England and Wales, this is invariably not the case. The legal purpose of such mechanisms is simply to give the sentencer a more accurate picture of the impact of the offence. ${ }^{117}$ As past empirical evaluations of various types of participatory initiatives have found, this situation leaves victims rather confused about the purpose or function of such schemes. ${ }^{118}$ It was therefore perhaps unsurprising that Sweeting et al arrived at similar conclusions in respect of the VAS; the researchers found that there was a lack of clarity and awareness on the part of victims as to the purpose and rationale of the mechanism.

It may be that victims' understandings of the scheme's operation has been influenced by the political rhetoric used to promote the scheme. Rock has noted that a leaflet given to the families in the VAS pilots informed them that:

'[t]hese statements give the families of murder and manslaughter victims a voice in the criminal justice system. Making a statement enables you to tell the court about how the murder or manslaughter has affected your family. ${ }^{119}$

Although a revised leaflet issued in February 2007 purported to make it clear that specific penal demands should not be made by families, Sweeting et al reported that most victims simply kept it for reference purposes only. ${ }^{120}$ Some nine years ago, when victim impact statements were first piloted in Britain, Edna Erez remarked that the English model for facilitating participation of the victim in sentencing makes little real difference to either victims or defendants

\footnotetext{
117 See The Victim's Advocate Protocol issued by the President of the Queen's Bench Division Setting Out the Procedure to be Followed in the Victims' Advocate Pilot Areas (2006), appended in Sweeting et al, above $\mathrm{n} 19$.

${ }^{118}$ See eg Hoyle et al, above n 26; Chalmers et al, above n 13.

119 Rock, above n.19, pp 9-10.

${ }^{120}$ Sweeting et al, above n 19, p 17.
} 
in the criminal justice system. ${ }^{121}$ Despite the national roll-out of the Victim Personal Statement Scheme, and the new measures contained in the Victim Focus Scheme, that analysis remains accurate.

The scheme is extremely limited in its scope. It applies only to a tiny proportion of victims (namely the families of homicide victims) who come to deal with the criminal justice system. Even then, it is unclear just who may claim to be a 'victim' for the purposes of providing a statement. ${ }^{122}$ One particular conundrum is posed by the fact that relatives of the deceased are likely to have been affected by the offence in different ways, and may not agree with one another on the nature and extent of the harm. For example, in cases of intra-familial homicide, including so-called 'honour killings' and 'mercy killings', it would not be unheard of for family members to hold very different perspectives on the rights and wrongs of the perpetrator's actions and the extent to which he or she should be punished. While Legal Guidance issued by the Crown Prosecution Service envisages that meetings with more than one 'victim' may be required, it is also made apparent that multiple victim personal statements should generally be avoided. ${ }^{123}$ Where the interests of different victims cannot be reconciled, it is unclear how the court should go about determining which components of which statement(s) to accept for the purposes of imposing a sentence.

A further divisive aspect of the scheme stems from the fact that it appears to have created an artificial hierarchy among victims, insofar as only families of homicide victims may rely on it. The vast majority of victims will still have noone to advance their views in the sentencing process. This limitation may,

${ }^{121}$ E Erez, 'Integrating A Victim Perspective In Criminal Justice Through Victim Impact Statements' in A Crawford and J Goodey (eds), Integrating a Victim Perspective Within Criminal Justice (Aldershot: Ashgate, 2000).

${ }^{122}$ See further $\mathrm{C}$ Brennan, above $\mathrm{n} 10$. Indeed, the task of constructing 'victims' generally can be fraught with difficulty, and there is no authoritative definition that can be applied across the legal order. See further Doak, above n 18, ch1.

${ }^{123}$ Crown Prosecution Service, 'Victim Focus Scheme Guidance on Enhanced CPS Service for Bereaved Families', para 27. Available:

http://www.cps.gov.uk/legal/v_to_z/victim_focus_scheme/[accessed 11 May 2009]. 
prima facie, seem justifiable on the ground that deceased victims - unlike those who have survived - will never be able to tell their stories in court. However, as we argued above, the adversarial system does not afford victims a realistic prospect of telling their stories at all. If one accepts that there is some value to the fact-finding process in allowing a certain category of victims to provide direct accounts to the sentencer, then surely the same logic dictates that all victims ought to be able to do so.

The limited nature of the scheme is perhaps unsurprising, given the narrow rationale which underpins it. The VFS is designed purely to afford the sentencer with a more accurate picture of past events. It is unfortunate that, despite the ascendancy of therapeutic jurisprudence and our expanding understanding of reparation, the scheme continues to conceptualise crime as an offence committed primarily against the state. Far from expanding the parameters of the criminal justice system to take account of the needs of victims and communities, the scheme as it stands serves to entrench the victim's position as a servant or agent of the state. ${ }^{124}$ Like many other recent initiatives promoted in the name of 'victims', the Victim Advocate Scheme has arguably been a product of astute political manoeuvring rather than a genuine willingness on the part of policymakers to engage in looking for ways to bolster the role of victims in the criminal justice system. ${ }^{125}$ This focus on what Bottoms has labelled 'populist punitiveness'126 has ultimately meant that efforts to identify and remedy the structural problems and complex valuebased questions have been significantly hampered.

The adversarial paradigm remains, at its core, fundamentally ill-equipped to provide a platform for the meaningful participation of victims, let alone heal individual conflicts between victims and offenders. Indeed, Sweeting et al's analysis of the scheme seemed to hint (albeit in somewhat vague terms) that

\footnotetext{
${ }^{124}$ Faulkner, above $\mathrm{n} 14$.

${ }^{125}$ See further $\mathrm{J}$ Jackson, 'Justice for All: Putting Victims at the Heart of Criminal Justice?' (2005) 30 JLS 309, 313; Doak, above n 18, ch 1; M Hall, above n 98, pp 80-83.

${ }^{126}$ A Bottoms, 'The philosophy and politics of punishment and sentencing' in C. Clarkson \& R. Morgan (eds) The Politics of Sentencing Reform (Oxford: Clarendon Press, 1995).
} 
the adversarial environment was incapable of sustaining any therapeutic function. The researchers described the family impact statement scheme as,

'an effort to construct a favourable public representation of the victim and his family, its medium could be a form of disjointed story-telling consisting of pointed anecdotes....and its audience was variously intended to be the defendant, the judge (who sometimes - but not always - acknowledged what was said at the point of sentencing), the jury and the wider world who were invited to understand the family's extraordinary loss, desolation and isolation., ${ }^{127}$

Whilst practitioners were aware of the fact that the family impact statement could not influence the actual sentence, a number of them nonetheless did recognise its potential for catharsis. ${ }^{128}$ This highlights the distinction drawn by Roberts and Erez between so-called 'communicative' models of victim participation and 'impact' models. ${ }^{129}$ As both the VAS and its successor, the VFS, stand, it is unclear whether they are primarily orientated towards catharsis or are intended simply to give the sentencer a better picture of past events. In either case, as Sweeting et al recommended, it is clear that victims' expectations must be managed, and they need to be made aware of the nature and extent of their input if the scheme is to be regarded as an effective and legitimate means of giving them a voice. ${ }^{130}$

If, however, policymakers did intend that catharsis should form at least part of the objective of the VAS, then the proposed VFS appears to be a peculiar way of achieving it. Under the original VAS, victims could either give an oral statement themselves, or through their advocate. Yet under the VFS, this provision is no longer in place. If victims wish to exercise their right to be heard, they now may only do so through their counsel. The removal of the

\footnotetext{
${ }^{127}$ ibid. at (12).

${ }^{128}$ Rock, above $\mathrm{n} 19$.

${ }^{129}$ Roberts and Erez, above $\mathrm{n} 101$.

${ }^{130}$ Sweeting et al., above $n 19, p 35$. This tends to be a feature of victim statement schemes generally - see Edwards, above $n 8$.
} 
ability of victims to be able to deliver a narrative in person was most probably calculated to avoid the risk of inflammatory statements, but it will undoubtedly undermine any therapeutic potential that direct account-making might have held. Although Sweeting et al found that the majority of families had asked for the statements to be read by the prosecutor or judge, a significant minority $(22 \%)$ had opted to present them in person. This was an opportunity that appeared to be valued by the families who did so, with the husband of one deceased victim telling the researchers that he was 'doing it because I just felt I owed it. ${ }^{, 131}$ Moreover, the researchers noted that overcoming the fear of speaking in court on such an emotional subject had helped victims to feel empowered and more satisfied with the process. It was also reported that there was a perception among practitioners that family members felt they could have a greater personal impact and 'do more to help' by delivering the FIS themselves. Although self-delivery of the statement tends to involve additional work for all stakeholders, it is regrettable that the therapeutic potential of the VFS has been curtailed by placing restrictions on the victim's role, rather than seeking to strengthen it.

As recent experience with the ICC illustrates, ${ }^{132}$ effective engagement with victims, especially when gauging the impact of emotional harm, should be conceived in more holistic terms, to include both pre and post trial phases. Seen against this background, ${ }^{133}$ domestic initiatives such as the VAS and VFI represent very small advances in the notion of victim participation. Unlike, the ICC, there are no pre-trial rights of participation which, in the domestic context, could provide the right for victims to present testimony having a direct bearing on charging decisions, subject to the rights of the accused and the need for a fair and impartial trial. Similarly, the right of victims in ICC trials to lead or challenge evidence pertaining to the guilt or innocence of the accused within the framework of agreed charges, and subject to appropriate fair trial

\footnotetext{
${ }^{131}$ ibid, 21.

132 Supra, note

${ }^{133}$ And whilst acknowledging the clear differences of rationale and process for international criminal trials.
} 
safeguards, also envisages a more interventionist role. ${ }^{134}$ Paradoxically, the normative detachment of victims in adversarial trial from the pursuit of economic as well as criminal justice goals renders them more 'acceptable'135 parties to the criminal process, yet advances for victims in international trial procedure have been achieved against the background of a perceptible shift away from the adversarial model in its archetypal form. ${ }^{136}$

Notwithstanding, these advances reflect a greater realisation of the international trial's transitional justice role, and its wider role as a fundamental pillar of governance in criminal justice. There are clear parallels here for domestic trial justice. For instance, it may be argued that shifts away from repressive forms of justice towards more hybridised forms of trial process are also transitional, in the sense that they represent a positive response to the failure of trial justice to engage with the justice expectations of the diverse groups and communities that comprise contemporary society. In this sense, therefore, fulfilling victims' rights of participation may symbolise a crossroads for trial justice.

\section{Conclusion}

The failure of the VFS to address the victim's therapeutic needs in a practical sense is a retrograde step. Paradoxically, however, it lends support to Sherman's case for an 'emotionally intelligent justice system'.137 Sherman envisages such a system working 'like an emotionally intelligent political campaign or product marketing plan, one that is likely to employ disaggregated strategies based on research evidence about what messages

\footnotetext{
${ }^{134}$ In the domestic context, this would challenge the adverse consequences of the adversarial distinction between verdict and sentence on establishing the factual basis for sentence.

${ }^{135}$ In the sense that their evidence is less likely to be perceived as tainted by an economic motive than in the pursuit of establishing the 'truth' of the events which constitute the facts alleged in the indictment.

${ }^{136}$ See further K Ambos, 'International Criminal Procedure: 'Adversarial', 'Inquisitorial' or Mixed?' (2003) 3 Int CLR 1.

${ }^{137}$ Sherman, above $\mathrm{n} 81$.
} 
or methods work best for each type of audience'. ${ }^{138}$ However, it is not sufficient that normative changes reflecting demands for greater accountability are based solely on empirical evidence. As Hudson suggests, in order to 'do justice to difference', ${ }^{139}$ in a coherent and practical way through the sentencing process, a radical change in penal ideology is required.

The shifts in the moral foundations which underpin concepts of fault and responsibility in the criminal law that we have discussed, and the changing relationship between what citizens receive and what they expect from the state in the administration of justice, suggest a gradual lessening in traditional resistance to ideological change. It is equally true to say that the benign influence of changes in international trial justice and international human rights standards alone are insufficient. One thing is certain, however; when procedures are viewed as fair, they will have a positive, therapeutic effect on the people involved, whereas when procedures are viewed as unfair they will have a negative, anti-therapeutic effect. ${ }^{140}$ Making victim participation a 'meaningful' reality involves recognising the crucial link between the perceived morality of the ideology which underpins criminal justice and perceptions of its fairness as an everyday reality by victim and the communities where they live. In a recent presidential address to the American Society of Criminology, Lawrence Sherman stated that a new window of opportunity is opening for criminology to reinvent justice, fuelled by widespread dissatisfaction with current practices and their costs. ${ }^{141}$ We believe that observation was particularly apt. The time may be ripe for criminology to advance a new paradigm of justice, which conceptualises crime in a different way; and seeks

\footnotetext{
${ }^{138}$ Ibid, citing D. Massey, 'Presidential Address. A Brief History of Human Society: The Origin and Role of Emotion in Social Life' (2002) 67 ASR 1.

${ }^{139}$ B Hudson, 'Doing Justice to Difference' in A Ashworth and M Wasik, (eds) Fundamentals of Sentencing Theory (Oxford: Clarendon Press, 1998)

${ }^{140}$ See J Wemmers and K Cyr, 'Can Mediation be Therapeutic for Crime Victims ? An Evaluation of Victims' Experiences in Mediation with Young Offenders' (2005) 47 Can J Criminol Crim Justice 527; EA Lind and $\mathrm{K}$ Van den Bos, 'When fairness works: Toward a general theory of uncertainty management' (2003) 24 Res Organ Behav 181; R MacCoun, 'Voice, Control and Belonging' (2005) 1 Ann Rev Law \& Soc Sci 171.

${ }^{141}$ Sherman, above $\mathrm{n} 81$,
} 
to bolster legitimacy through promoting the effective participation of victims and communities. ${ }^{142}$ While recent years have seen commentators become bolder in suggesting ways in which this might be accomplished, ${ }^{143}$ a fundamental re-evaluation of the values and structures of criminal justice system by policymakers remains an indeterminate prospect.

${ }^{142}$ This article has focused on the desirability of victim participation within criminal justice, but many commentators have also recognised the need for effective community engagement. See eg. A Crawford, 'The Spirit of Community: Rights, Responsibilities and the Communitarian Agenda' (1996) 23 JLS 247, The Local Governance of Crime: Appeals to Community and Partnerships (Oxford: Clarendon, 1997); D O'Mahony and J Doak, 'The Enigma of Community and the Exigency of Engagement: Restorative Youth Conferencing in Northern Ireland' (2006) 4 BJCJ 9; G. Pavlich, 'The Force of Community' in H Strang and J. Braithwaite (eds.), Restorative Justice and Civil Society (Cambridge: Cambridge University Press, 2001).

${ }^{143}$ See eg M Cavadino and J Dignan, 'Towards a Framework for Conceptualising and Evaluating Models of Criminal Justice from a Victim's Perspective' (1996) 4 IRV 153; Pizzi, above $\mathrm{n} \mathrm{96;} \mathrm{L} \mathrm{Walgrave,} \mathrm{'Restorative} \mathrm{Justice} \mathrm{and} \mathrm{the} \mathrm{Law:} \mathrm{Socio-Ethical} \mathrm{and} \mathrm{Juridical}$ Foundations for a Systemic Approach' in L Walgrave (ed) Restorative Justice and the Law (Cullompton: Willan Publishing, 2002); J Jackson 'The Effect of Human Rights on Criminal Evidentiary Processes: Towards Convergence, Divergence or Realignment?' (2005) 68 MLR 737; Doak, above n 18. 